\title{
EL PROBLEMA DE LA JUSTICIABILIDAD DE LOS DECRETOS DE DECLARACIÓN Y DE PRÓRROGA DEL ESTADO DE ALARMA
}

\author{
Carlos Garrido López \\ Profesor Titular de Derecho Constitucional, \\ Universidad de Zaragoza
}

Cómo citar este artículo / Citation: Garrido López, C. (2021). El problema de la justiciabilidad de los decretos de declaración y de prórroga del estado de alarma. Garrido López, C. (coord.) Excepcionalidad y Derecho: el estado de alarma en España, Colección Obras colectivas, Fundación Manuel Giménez Abad, Zaragoza.

DOI: https://doi.org/10.47919/FMGA.OC21.0007

SUMARIO: I. ALARMA GUBERNAMENTAL Y ALARMA PARLAMENTARIA. DIVERSIDAD DE PROCEDIMIENTOS Y DE PARTÍCIPES Y DUDAS SOBRE SU CONTROL JURISDICCIONAL. II. EL PROBLEMA DE LA JUSTICIABILIDAD DE LOS DECRETOS DE DECLARACIÓN Y DE PRÓRROGA DEL ESTADO DE ALARMA EN LA DOCTRINA: 1. La tesis de los decretos de declaración y de prórroga del estado de alarma como actos de gobierno sólo sometidos, en su caso, al control jurisdiccional de sus elementos reglados. 2. Los decretos de declaración y de prórroga del estado de alarma como disposiciones reglamentarias revisables por la jurisdicción contenciosoadministrativa. 3. Los decretos de declaración y de prórroga del estado de alarma como actos con fuerza de ley reservados al control de la justicia constitucional. III. EL PROBLEMA DEL CONTROL JURISDICCIONAL DE LOS DECRETOS DE DECLARACIÓN Y DE PRÓRROGA DEL ESTADO DE ALARMA ANTE EL TRIBUNAL SUPREMO $Y$ EL TRIBUNAL CONSTITUCIONAL: 1. La autorización parlamentaria de la prórroga como causa de la falta de jurisdicción del Tribunal Supremo sobre los decretos de declaración y de prórroga del estado de alarma de 2010. 2. La consideración de los decretos de declaración y de prórroga de 2010 como actos con fuerza de ley por la STC 83/2016, de 28 de abril, dictada a resultas de un proceso de amparo. 3. Los decretos de declaración y de prórroga del estado de alarma de 
2020 ante el Tribunal Supremo: de nuevo la tesis de la intervención parlamentaria como causa de la falta de jurisdicción y la conjetura sobre su doble naturaleza jurídica. IV. EPÍLOGO: A LA ESPERA DEL PROCESO DE INCONSTITUCIONALIDAD QUE CONFIRME LA FUERZA DE LEY Y LA RESERVA DEL CONTROL DE LOS DECRETOS DE DECLARACIÓN Y DE PRÓRROGA DEL ESTADO DE ALARMA A LA JURISDICCIÓN CONSTITUCIONAL

\section{ALARMA GUBERNAMENTAL Y ALARMA PARLAMENTARIA. DIVERSIDAD DE PROCEDIMIENTOS Y DE PARTÍCIPES $Y$ DUDAS SOBRE SU CONTROL JURISDICCIONAL}

El artículo 116.2 de la Constitución (CE) habilita al Gobierno para constatar la concurrencia de los supuestos de emergencia y declarar el estado de alarma, en todo o en parte del territorio nacional, por un plazo máximo de quince días, dando cuenta de ello al Congreso de los Diputados, que ha de reunirse de inmediato a estos efectos. De prolongarse la situación de emergencia, el Gobierno puede solicitar la prórroga, pero en esta ocasión no decide sobre su contenido. La prórroga del estado de alarma corresponde autorizarla al Congreso, quien "podrá establecer el alcance y las condiciones vigentes" durante su vigencia, como subraya el artículo. 6.2. in fine de la Ley Orgánica 4/1981, de 1 de julio, de los estados de alarma, excepción y sitio (LOAES). Esta diferencia en la regulación de la competencia según que la duración supere o no los quince días ha llevado a la doctrina a distinguir entre un estado de alarma "gubernamental" y otro "parlamentario" o, al menos, compartido1.

El estado de alarma es declarado mediante decreto acordado en Consejo de Ministros, a instancia del propio Gobierno o a solicitud del presidente de una Comunidad Autónoma, o de varias, cuando los supuestos de hecho excepcionales referidos en el artículo 4 de la LOAES afecten exclusivamente a todo o parte del territorio autonómico correspondiente. El decreto de declaración debe determinar el ámbito territorial, la duración y los efectos del estado declarado. Y también la autoridad competente en el caso de que el Gobierno, al que el legislador reserva la gestión de la emergencia, decida

1 CRUZ VILLALÓN, P., "El nuevo derecho de excepción", Revista Española de Derecho Constitucional, núm. 2, 1981, p. 105, y, del mismo autor, Estados excepcionales y suspensión de garantías, Tecnos, Madrid, 1984, pp. 72-74. 
delegarla en los presidentes autonómicos cuando la declaración afecte a todo o parte de los territorios de sus comunidades respectivas, según prevé el artículo 7 de la LOAES2. El Gobierno está obligado a dar cuenta de la declaración al Congreso de los Diputados, suministrándole la información requerida, pero ello no altera el carácter exclusivo de la competencia gubernamental ni afecta al contenido de la declaración3.

2 En el estado de alarma declarado mediante Real Decreto 900/2020, de 9 de octubre, y delimitado territorialmente a varios municipios de la Comunidad Autónoma de Madrid, la autoridad competente fue el Gobierno de la Nación. En las otras tres ocasiones en que el estado de alarma ha sido declarado en España, el Gobierno ha delegado su autoridad en varias autoridades estatales y/o autonómicas en función de la singularidad y la naturaleza de la emergencia, como el jefe del Estado Mayor del Ejército del Aire (art. 6 del Real Decreto 1673/2010, de 4 de diciembre, por el que se declara el estado de alarma para la normalización del servicio público esencial del transporte aéreo), los ministros de Sanidad, Defensa, Interior y Transportes, Movilidad y Agenda Urbana, bajo la superior dirección del presidente del Gobierno (art. 4.2 del Real Decreto 463/2020, de 14 de marzo, por el que se declara el estado de alarma para la gestión de la situación de crisis sanitaria ocasionada por el Covid-19), el ministro de Sanidad, bajo la superior dirección del presidente del Gobierno, y, con arreglo al principio de cooperación con las CC.AA., los presidentes de cada comunidad en su respectivo territorio, y sólo los presidentes de las CC.AA. "para la adopción, supresión, modulación y ejecución de medidas correspondientes a la fase III del plan de desescalada" (art. 6 del Real Decreto $555 / 2020$, de 5 de junio, que prorrogó por sexta vez el estado de alarma declarado el 14 de marzo) y, finalmente, los presidentes de las CC.AA. y de las ciudades autónomas de Ceuta y Melilla, quienes quedaron habilitados para dictar las órdenes, resoluciones y disposiciones para la aplicación de lo previsto en los artículos 5 a 11 del Decreto de declaración y para modular, flexibilizar y suspender la aplicación de las medidas previstas en sus artículos 6,7 y 8 "a la vista de la evolución de los indicadores sanitarios, epidemiológicos, sociales, económicos y de movilidad" (arts. 2.2 y 10 del Real Decreto 926/2020, de 25 de octubre, por el que se declara el estado de alarma para contener la propagación del SARS-CoV-2, respectivamente). Estas delegaciones por parte del Gobierno de la Nación, y particularmente la realizada a los presidentes de las CCAA y de las ciudades autónomas, ha merecido el reproche de la doctrina, tanto por no estar prevista en el artículo 7 de la LOAES, como por la falta de fijación de los criterios en virtud de los cuales se pueden limitar derechos y la discrecionalidad que se otorga a los presidentes autonómicos para hacer efectivas, o no, dichas limitaciones. Por todos, véanse HERBÓN COSTAS, J. J., "El mando y gestión del estado de alarma", en BIGLINO CAMPOS, P. y DURÁN ALBA, J. F. (dirs.), Los efectos horizontales de la COVID sobre el sistema constitucional: estudios sobre la primera oleada, Fundación Manuel Giménez Abad, Zaragoza, 2020, pp. 17-18 (disponible en: https://www.fundacionmgimenezabad.es/es/losefectos-horizontales-de-la-covid-19-sobre-el-sistema-constitucional-estudios-sobre-la-primera); TAJADURA TEJADA, J., "Estado de alarma y seguridad jurídica", El País, 27 de octubre de 2020 (disponible en: https://elpais.com/opinion/2020-10-26/estado-de-alarma-y-seguridadjuridica.html), y RUIZ ROBLEDO, A., "El estado de alarma: donde quiere el gobernante", El País, 6 de noviembre de 2020 (disponible en: https://elpais.com/opinion/2020-11-05/el-estadode-alarma-donde-quiere-el-gobernante.html).

3 La intervención de la Cámara es "de naturaleza estrictamente política, de modo que el Gobierno no queda vinculado jurídicamente por las decisiones parlamentarias que pudieran adoptar, ni condiciona ni altera el contenido del decreto por el que se ha llevado a cabo la declaración del estado de alarma". Cfr. SOLOZÁBAL ECHAVARRÍA, J. J., "Algunas consideraciones constitucionales sobre el estado de alarma", en BIGLINO CAMPOS, P. y DURÁN ALBA, F. (coords.), Los efectos horizontales de la COVID sobre el sistema constitucional: estudios sobre la primera oleada, cit., p. 15. 
De resultar necesario prolongar la situación de emergencia más allá de quince días, la prórroga del estado de alarma debe ser autorizada por el Congreso de los Diputados. A diferencia de la declaración, decidida unilateralmente por el Gobierno, la prórroga ha sido configurada en nuestro ordenamiento jurídico como una decisión compleja en la que la iniciativa parte del Gobierno, la constatación de la necesidad y la determinación de las condiciones corresponde al Congreso y la formalización de la decisión se atribuye nuevamente al Gobierno mediante decreto4. Ello altera la naturaleza del estado prorrogado, ahora esencialmente parlamentario, "por cuanto el decreto gubernamental [...] viene a ser la proclamación formal de la autorización congresual"5. Con todo, el Gobierno no está obligado a dictarlo. La autorización parlamentaria de la prórroga es preceptiva y sus términos son vinculantes; pero carece de eficacia jurídica en tanto el contenido autorizado no se plasme en el correspondiente decreto gubernamental. La autorización parlamentaria de la prórroga es, por tanto, un acto parte que, no obstante ser necesario para la adopción de la decisión y determinar su contenido, no activa por sí solo la prórroga; ni fuerza "necesariamente" su activación, porque en el trascurso del procedimiento pueden desaparecer las circunstancias que justificaban la prórroga o disminuir su gravedad, haciéndola innecesaria. La prórroga, en suma, sólo existe si el Gobierno la formaliza, lo que le permite seguir siendo el titular de la decisión de excepción.

La CE y la LOAES regulan el procedimiento y los órganos que participan en la adopción de los decretos de declaración y de prórroga del estado de alarma. La LOAES ha previsto por su parte los presupuestos habilitantes, el alcance y los posibles efectos de dichos decretos. Pero ni la CE ni la LOAES han concretado las garantías jurisdiccionales existentes para controlar que su adopción y

\footnotetext{
4 Según el artículo 162, apartados 2 a 5, del Reglamento del Congreso de los Diputados (RC), si el Gobierno pretende la prórroga debe solicitar la autorización parlamentaria antes de que expire el plazo de quince días del estado declarado. Formulada la solicitud, los grupos parlamentarios pueden presentar propuestas sobre el alcance y las condiciones de la prórroga hasta dos horas antes del inicio de la sesión en que ha de debatirse la concesión de la autorización. Dicho debate se desarrolla en el Pleno, iniciándose con la exposición por un miembro del Gobierno de las razones que justifican la solicitud. Concluido el debate según las normas previstas para los de totalidad, procede votar la solicitud y las propuestas presentadas. Y obtenida una decisión de la Cámara, para lo que no se exige mayoría cualificada alguna, se da traslado de su contenido al Gobierno. Sobre los problemas que puede suscitar el procedimiento, SERRANO ALBERCA, J. M., "Comentario al artículo 116", en GARRIDO FALLA, F. (dir.), Comentarios a la Constitución, 3ae ed., Civitas, Madrid, 2001, p. 1783.

5 NAVAS CASTILLO, A., "Los estados excepcionales y su posible control por el Tribunal Constitucional", Revista de la Facultad de Derecho de la Universidad Complutense, núm. 87, 1997, p. 150.
} 
contenido sean conformes a Derecho. La Ley Orgánica 2/1979, de 3 de octubre, del Tribunal Constitucional (LOTC) o alguna de sus posteriores reformas podían haber incluido expresamente los decretos de declaración y de prórroga de los estados de alarma y de excepción entre el elenco de normas y actos susceptibles de declaración de inconstitucionalidad contenido en su artículo 27.2, pero no lo hizo. Al amparo del artículo 161.1.d) de la CE, que permite conocer al Tribunal Constitucional "de las demás materias que le atribuyan la Constitución y las leyes", la LOAES podía haberle asignado la competencia para controlar la declaración y la prórroga del estado de alarma, o remitirla a la jurisdicción contencioso-administrativa, pero tampoco dio el paso. Cierto es que el legislador tampoco señaló expresamente el orden jurisdiccional competente al subrayar en el artículo 3.1 de la LOAES que los actos y disposiciones de la Administración pública adoptados durante la vigencia del estado de alarma son impugnables en vía jurisdiccional, y nadie dudó de que ese orden sería fundamentalmente el contencioso-administrativo, sin perjuicio de que pudieran impugnarse ante otros órdenes atendiendo a la naturaleza y a la forma jurídica de dichos actos. Pero no ocurrió así con las decisiones de declaración y de prórroga del estado de alarma, porque las singularidades de los decretos que las formalizan, derivadas de sus efectos y su procedimiento de adopción, suscitaron numerosas dudas sobre su posible control jurisdiccional. Debido al alcance político de estas decisiones, alguna doctrina sostuvo que debían quedar exentas de control o limitarse este a sus elementos reglados. Atendiendo a su condición formal de decretos, otra doctrina defendió su revisión ante la jurisdicción contencioso-administrativa. Ciertos autores consideraron factible el control contencioso-administrativo del decreto de declaración, pero no del decreto de prórroga autorizado por el Congreso. Y no faltó quien, otorgando relevancia a su incidencia sobre las leyes y disposiciones con rango de ley, consideró que el control de ambos decretos debía residenciarse en todo caso ante la justicia constitucional.

Durante más de tres décadas, el dilema no trascendió del plano teórico, pero la situación cambió tras la declaración del primer estado de alarma en nuestro país, que se produjo el 4 de diciembre de 2010 como consecuencia del abandono concertado y masivo de los controladores de tránsito aéreo de sus puestos en las torres y centros de control de los aeropuertos españoles. Considerando ilegal la declaración e injustificada la prórroga, los controlares interpusieron varios recursos contencioso-administrativos contra los decretos 
de declaración y de prórroga del estado de alarma ante el Tribunal Supremo. E inadmitidos dichos recursos por falta de jurisdicción, los controladores reclamaron en amparo la autorización de la prórroga y, más tarde, también en amparo, los decretos de declaración y de prórroga del estado de alarma, pero sin éxito, porque, aunque admitidas a trámite, las demandas de amparo fueron rechazadas y el control de ambos decretos quedó descartado. El problema de la justiciabilidad de los decretos de declaración y de prórroga del estado de alarma ha vuelto, sin embargo, a plantearse en la primavera de 2020 con ocasión del estado de alarma declarado para la gestión de la crisis sanitaria provocada por la covid-19. Dada la intensidad de las restricciones a la libertad de circulación y la afección de otros derechos conexos, el decreto de declaración y varios de los decretos de prórroga fueron nuevamente recurridos ante la jurisdicción contencioso-administrativa, esta vez por el cauce procedimental de la protección jurisdiccional de los derechos de la persona, e impugnados en amparo por vulneración de la tutela judicial efectiva y, por primera vez, mediante un recurso de inconstitucionalidad presentado por los diputados del Grupo Parlamentario Vox, cuya resolución, todavía pendiente, permitirá al Tribunal Constitucional zanjar en un proceso de inconstitucionalidad, con alcance general y eficacia erga omnes, las dudas y reticencias que cierta doctrina y la jurisdicción ordinaria todavía mantienen sobre la posición en el sistema de fuentes de los decretos de declaración y de prórroga del estado de alarma y la jurisdicción competente para revisarlos.

En este trabajo expondré, en su primera parte, las diversas opiniones formuladas por la doctrina sobre la naturaleza y el posible control jurisdiccional de los decretos de declaración y de prórroga del estado de alarma. En su segunda parte, sintetizaré los razonamientos jurídicos contenidos, hasta el momento, en los Autos del Tribunal Supremo que inadmitieron los recursos contra la declaración y la prórroga del estado de alarma decretado en 2010 aduciendo la autorización parlamentaria de la prórroga como causa de la falta de jurisdicción; en la Sentencia 83/2016, de 28 de abril, del Tribunal Constitucional, en la que, tras considerar la cuestión objeto de amparo "nuclear, novedosa y de indiscutible relevancia constitucional", el TC caracterizó dichos decretos como actos del Estado con fuerza de ley sólo susceptibles de control de constitucionalidad; y en los Autos del Tribunal Supremo que, dictados en mayo de 2020, inadmitieron los recursos contencioso-administrativos interpuestos contra los decretos de declaración y de prórroga del estado de 
alarma para la gestión de la emergencia sanitaria y en los que el Alto Tribunal ha conjeturado sobre su naturaleza alternativa: la de actos con fuerza de ley si se autoriza la prórroga y la de meros reglamentos de no autorizarse.

\section{EL PROBLEMA DE LA JUSTICIABILIDAD DE LOS DECRETOS DE DECLARACIÓN Y DE PRÓRROGA DEL ESTADO DE ALARMA EN LA DOCTRINA}

El estado de alarma se declara por el Gobierno mediante decreto. La prórroga del estado de alarma corresponde también al Gobierno mediante decreto, pero sus condiciones no pueden ser otras que las fijadas en la autorización parlamentaria. Por su contenido excepcional, alguna doctrina sostuvo que ambos tipos de decretos eran actos políticos o de gobierno totalmente exentos de control jurisdiccional o sólo revisables en sus elementos constitucionalmente reglados por la justicia constitucional. A juicio de otra doctrina, ambos tipos de decretos debían considerarse, atendiendo a su forma jurídica, disposiciones reglamentarias o reglamentos de necesidad cuyo control ha de corresponder a la jurisdicción contencioso-administrativa. Ciertos autores atribuyeron naturaleza reglamentaria a los decretos de declaración, pero no a los decretos de prórroga porque la autorización parlamentaria que precisan los cualifica jurídicamente al punto de conferirles fuerza y valor de ley. El control de los primeros, correspondería, por ello, a la jurisdicción ordinaria, y el de los segundos, a la justicia constitucional. Algún autor, finalmente, valorando la identidad de sus efectos sobre el ordenamiento jurídico, caracterizó tanto a los decretos de declaración como a los decretos de prórroga como actos con fuerza de ley al amparo de la categoría prevista en el artículo 27.2.b) de la LOTC y, por tanto, tan sólo susceptibles de control de constitucionalidad.

\section{La tesis de los decretos de declaración y de prórroga del estado de alarma como actos de gobierno sólo sometidos, en su caso, al control jurisdiccional de sus elementos reglados}

De tous les actes dont l'adoption constitue l'exercice de l'état de nécessité -afirmó Camus-, c'est la decisión de déclenchement qui présente la plus grande portée politique: elle est la source de toutes les décisions ultérieures, et surtout c'est elle qui apporte le plus grand bouleversement à l'ordre constitutionnel démocratique à partir de l'appréciation d'une situation 
formée essentiellement d'éléments d'ordre politique6. Debido a este extraordinario alcance político, alguna doctrina incluyó las decisiones excepcionales en la categoría de los actes de gouvernement o de las political questions ${ }^{7}$. Conforme a esta tesis, los decretos gubernamentales de declaración y de prórroga de los estados excepcionales serían, pese a su formalización jurídica, actos políticos o de gobierno ajenos al Derecho administrativo y exentos, en virtud del principio de separación de poderes, de todo control jurisdiccional. En tanto que actos del Gobierno carentes de valor de ley, su control no podía ser residenciado ante el Tribunal Constitucional. Y al adoptarse bajo habilitación constitucional expresa, tampoco serían susceptibles de revisión contencioso-administrativa.

En este sentido se pronunciaron Fernández Segado y Serrano Alberca. El primero sostuvo que, pese a su forma jurídica externa, los decretos de declaración y de prórroga del estado de alarma no eran reglamentos, sino actos del Gobierno cuyo control debía ser político y no jurídico ${ }^{8}$. Por su parte, Serrano Alberca afirmó que dichos decretos eran simples "actos condición" por medio de los cuales se activan los preceptos de la LOAES. Al adoptarlos, el Gobierno podía vulnerar lo establecido en la propia LOAES, pero, en su opinión, los tribunales no podían controlar los decretos excepcionales cuyo contenido hubiera sido autorizado por el Congreso, ni la declaración del estado de alarma por el Gobierno al estar basada en criterios de oportunidad ${ }^{9}$. En un trabajo posterior, Serrano Alberca subrayó las semejanzas de los decretos excepcionales cuya adopción requiere autorización parlamentaria con la legislación delegada precedida de una ley formal de bases, pero rechazó la

\footnotetext{
${ }^{6}$ CAMUS, G., L'état de nécessité en démocratie, Librairie générale de droit et de jurisprudence, Paris, 1965, p. 346. Sobre las dificultades de la revisión judicial de las decisiones excepcionales por su alcance político, también GREENE, A., Permanet States of Emergency and the Rule of Law. Constitutions in an Age of Crisis, Hart Publishing, Oxford, 2018, pp. 113119.

Sobre la doctrina de los actes de gouvernement elaborada por la jurisprudencia francesa, GARRIDO CUENCA, N., El acto de gobierno, Cedecs, Barcelona, 1998, pp. 77-134. Sobre las llamadas political questions, véanse ALONSO GARCÍA, E., "EI Tribunal Burger y la doctrina de las polítical questions en los Estados Unidos", Revista Española de Derecho Constitucional, núm. 1, 1981, pp. 287-299, y DALY, P., "Justiciability ant the 'Political Question' Doctrine", Public Law, num. 1, 2010, pp. 160-178.

8 FERNÁNDEZ SEGADO, F., El estado de excepción en el derecho constitucional español, Edersa, Madrid, 1977, p. 25, y, del mismo autor, "La Ley Orgánica de los estados de alarma, excepción y sitio", Revista de Derecho Político, núm. 11, 1981, pp. 98-99.

SERRANO ALBERCA, J. M., "Situaciones excepcionales y fuentes del Derecho en la Constitución española de 1978", en VV.AA., La Constitución española y las fuentes del Derecho, vol. III, Instituto de Estudios Fiscales, Madrid, 1979, pp. 1969-1971.
} 
posibilidad de controlar, como ocurre en el caso de la legislación delegada, la eventual extralimitación de los decretos respecto de las autorizaciones correspondientes. "En primer lugar, porque materialmente estos actos de declaración son actos políticos cuyo control debe ser político; en segundo lugar, porque, desde un punto de vista formal, ni la autorización es una ley ni el decreto es una disposición normativa con fuerza de ley, por lo que resultaría forzado tratar de encajar estos actos en la categoría de disposiciones contra las que cabe el recurso de inconstitucionalidad" ${ }^{10}$.

En una línea similar, Mateu-Ros y Cerezo afirmó que los decretos de declaración y de prórroga del estado de alarma eran actos políticos ajenos a la jurisdicción contencioso-administrativa "porque aquí el Gobierno no está actuando en su faceta de órgano superior de la Administración del Estado sino en la de órgano político comisionado para realizar actividades supra o extraadministrativas". En el supuesto de declaración injustificada de un estado de alarma, la responsabilidad sería exigible en términos políticos, no jurídicamente en atención a la ilegalidad del acto. Y lo mismo cabía decir del decreto de prórroga del estado de alarma, pues la previa autorización del Congreso de los Diputados "constituye una técnica de habilitación interorgánica que no trasciende a términos resolutorios externos" $y$, a la postre, no afecta a la calificación política del acto $^{11}$. Pese a conferirles esta naturaleza, Mateu-Ros consideró que no deberían estar exentos de todo control. Los decretos de declaración y de prórroga del estado de alarma son actos del Gobierno adoptados en razón de una habilitación constitucional expresa, por lo que, a su juicio, cabría someter sus elementos reglados al control del Tribunal Constitucional (TC) ya que su carácter político no impide verificar su constitucionalidad. "El acto político -subrayó el autor- es un acto extraño a la esfera del Derecho administrativo en atención al órgano que lo dicta y a la función que en este caso está ejerciendo. Pero la jurisdicción constitucional tiene un significado distinto: emite un juicio de legalidad constitucional en el que entran en juego todos los elementos jurídico-políticos propios de las normas de una Constitución y al que debe reconocerse la máxima amplitud dentro del

\footnotetext{
${ }^{10}$ SERRANO ALBERCA, J. M., "Comentario al artículo 116”, cit., pp. 1787-1788.

${ }^{11}$ MATEU-ROS Y CEREZO, R., "Estados de alarma, excepción y sitio", en VV.AA., Gobierno y Administración en la Constitución, vol. I, Instituto de Estudios Fiscales, Madrid, 1988, p. 193.
} 
espectro de autorizaciones, aprobaciones, decisiones actos políticos en suma que pueblan el universo constitucional" ${ }^{12}$.

Durante mucho tiempo, la caracterización de un acto como político fue sinónimo en nuestro país de imposible fiscalización judicial ${ }^{13}$, pero, tras la aprobación de la CE, lo político pasó a ser la cualidad de ciertos actos que, no obstante su naturaleza política, podían ser fiscalizados en determinados supuestos, como reconoció Mateu-Ros en relación con los decretos de declaración y de prórroga del estado de alarma. Tras la CE, en efecto, los actos de dirección política definidos legislativamente pudieron ser revisados por la jurisdicción ordinaria en sus aspectos formales o "jurídicamente asequibles", como subrayó el Tribunal Supremo, sin afectar al fondo de la decisión gubernamental $^{14}$. Y los elementos constitucionalmente reglados de los actos adoptados en virtud de previsión constitucional expresa y su debido respeto a los derechos fundamentales fueron admitidos como objeto de control por la jurisdicción constitucional. En este sentido se pronunciaron las SSTC 45/1990, de 15 de marzo, 196/1990, de 29 de noviembre, y 220/1991, de 25 de noviembre, al proclamar la sujeción a la CE de los actos del Gobierno no sometidos al Derecho administrativo y la posibilidad de que dichos actos fueran recurridos directamente en amparo ante el TC en caso de carecer de control

\footnotetext{
12 Ibidem, p. 195.

Sobre la doctrina del acto político o de Gobierno bajo la Ley de Santamaría de Paredes de 1888 y tras la Ley de 27 de diciembre de 1956, reguladora de la jurisdicción contenciosoadministrativa, véase GARRIDO CUENCA, N., El acto de gobierno, cit., pp. 393-440.

${ }^{14}$ Véanse, en este sentido, las SSTS de 6 de noviembre de 1984, de 29 de noviembre de 1985, de 9 de junio de 1987, de 30 de julio de 1987 y de 15 de noviembre de 1988. El ATS de 18 de enero de 1993 y la STS de 28 de junio de 1994, sobre el nombramiento del Fiscal General del Estado, reconocieron la existencia objetiva de actos de dirección política del Gobierno, pero declararon la competencia de la jurisdicción contencioso-administrativa para controlar dichos actos mediante los llamados "conceptos judicialmente asequibles", esto es, los elementos reglados del acto y la interpretación de los conceptos jurídicos indeterminados que definen la potestad correspondiente. $Y$ sentencias posteriores del TS, singularmente las tres dictadas el 4 de abril de 1997 sobre la desclasificación de los "papeles del CESID", confirmaron la tesis de los "conceptos judicialmente asequibles" y su control por la jurisdicción contenciosoadministrativa. A fin de zanjar normativamente la cuestión, el artículo 2.a) de la Ley 29/1998, de 13 de julio, reguladora de la jurisdicción contencioso-administrativa (LJCA) sometió expresamente a control los actos y disposiciones del Gobierno y de los Consejos de Gobierno de las Comunidades Autónomas "cualquiera que fuere la naturaleza de dichos actos" por lo que respecta a "la protección de los derechos fundamentales, a los elementos reglados del acto y a la determinación de las indemnizaciones que fueran procedentes". Sobre el alcance del artículo 2.a) LJCA, vid. GÓMEZ MONTORO, A. J., "El control jurisdiccional del Gobierno", en ARAGÓN REYES, M. y GÓMEZ MONTORO, A. J., (coords.): El Gobierno. Problemas constitucionales, Centro de Estudios Políticos y Constitucionales, Madrid, 2005, pp. 477-502.
} 
jurisdiccional ordinario, a semejanza de lo establecido en el artículo 42 de la LOTC para los actos parlamentarios sin valor de ley ${ }^{15}$.

"Este Tribunal -se afirmó en el fundamento jurídico 5 de la STC 196/1990- ha señalado recientemente que «no toda actuación del Gobierno, cuyas facultades se enuncian en el artículo 97 del Texto constitucional, está sujeta al Derecho administrativo. Es indudable, por ejemplo, que no lo está, en general, la que se refiere a las relaciones con otros órganos constitucionales, como son los actos que regula el título V de la Constitución» (STC 45/1990). Quiere decirse con ello que en tales casos el Gobierno actúa como órgano político y no como órgano de la Administración, no ejerce potestades administrativas ni dicta actos de esta naturaleza y, por lo mismo, su actuación no puede calificarse como administrativa cuyo control corresponda exartículos 106.1 de la Constitución y 8 de la Ley Orgánica del Poder Judicial a los tribunales de justicia. [...] Tales actos producidos en el seno de las citadas relaciones entre Gobierno y Parlamento agotan por lo general sus efectos en el campo estrictamente parlamentario, dando lugar en su caso, al funcionamiento de instrumentos de control político. [...] Ahora bien, ello no excluye que, excepcionalmente, en el desarrollo de esas relaciones institucionales se pueda ver comprometido el ejercicio de los derechos fundamentales [...], bien por el Ejecutivo, bien por los propios órganos de las Cámaras". Y en esos casos, cabría someter directamente la revisión de dichos actos al control, mediante amparo, de la jurisdicción constitucional.

Consecuentemente, pese a su alcance y su supuesta naturaleza de actos políticos, los decretos de declaración y de prórroga del estado de alarma podrían ser, llegado el caso, en cuanto actos autoaplicativos que limitan por sí mismos derechos y permiten la imposición de sanciones, impugnados en amparo ante el TC por violación de derechos fundamentales por quienes fueran sus titulares, por el Defensor del Pueblo o por el Ministerio Fiscal (art. 43 de la LOTC). Su supuesta naturaleza de actos del Gobierno sin valor de ley, aunque exentos de control contencioso-administrativo por su naturaleza política o limitado este a sus elementos reglados, como ha sostenido esta doctrina, no impediría que pudieran vulnerar directamente derechos fundamentales, lo que posibilitaría su impugnación y su control extraordinario de fondo por la justicia constitucional.

\footnotetext{
${ }^{15}$ En parecido sentido, véanse, asimismo, los AATC 360/1990, de 5 de octubre, y 426/1990, de 10 de diciembre.
} 


\section{Los decretos de declaración y de prórroga del estado de alarma como disposiciones reglamentarias revisables por la jurisdicción contencioso-administrativa}

Para otra doctrina, los decretos gubernamentales de declaración y de prórroga del estado de alarma serían, atendiendo al instrumento usado para su formalización jurídica, disposiciones reglamentarias susceptibles de control de legalidad por la jurisdicción contencioso-administrativa. "[...] el Tribunal Supremo -afirmó Rodríguez Oliver- podrá anular la declaración de la alarma en cuanto que no se ajuste a los requisitos de forma o de procedimiento, 0 conlleve una suspensión de derechos prohibida por el artículo 55.1 CE, o bien no se acomode a los concretos supuestos de hecho que pueda establecer la futura Ley Orgánica en cuanto que estos funcionarán como conceptos jurídicos indeterminados, o en fin, incurra en desviación de poder" ${ }^{16}$. Mayores problemas le suscitó al autor, sin embargo, la caracterización jurídica de los decretos de prórroga del estado de alarma debido a la preceptiva autorización previa del Congreso de los Diputados. $Y$ atendiendo a esa intervención parlamentaria, atribuyó dos naturalezas alternativas a dichos decretos: la de mera formalización reglada de un acto parlamentario sin valor de ley, exenta de control jurisdiccional, y la de disposición reglamentaria revisable por el Tribunal Supremo en el supuesto y en los aspectos en que el decreto de prórroga resultara ultra vires. De ajustarse a los términos de la autorización, el decreto de prórroga del estado de alarma proporcionaría eficacia jurídica externa a acuerdos parlamentarios sin valor de ley y sería inmune a la jurisdicción contencioso-administrativa. Pero si el decreto de prórroga se extralimitara yendo más allá de lo autorizado, recuperaría su naturaleza reglamentaria y podría ser anulado por el Tribunal Supremo al contravenir su presupuesto legitimador ${ }^{17}$.

Para Cruz Villalón y Lafuente Balle, los decretos de declaración del estado de alarma tendrían, asimismo, naturaleza reglamentaria, siendo por ello susceptibles de control jurisdiccional por violación de la LOAES. Y naturaleza

\footnotetext{
${ }^{16}$ RODRíGUEZ OLIVER, J. Ma‥, "Los ámbitos exentos del control del Tribunal Constitucional español", en VV.AA., El Tribunal Constitucional, vol. III, Instituto de Estudios Fiscales, Madrid, 1981 , p. 2316.

17 Ibidem, pp. 2317-2318.
} 
reglamentaria tendrían también, a su juicio, los decretos de prórroga del estado de alarma porque, pese a ser comparables en su relación con la autorización parlamentaria con los decretos legislativos en su relación con la delegación legislativa, serían "poco más que un requisito formal" de la entrada en vigor de la prórroga del estado de alarma y, como normas que formalizan hacia el exterior lo autorizado, serían "susceptibles de control jurisdiccional, un control de legalidad que operará respecto de la LOAES, tanto directamente como indirectamente, por violación de la autorización del Congreso" ${ }^{18}$. Y en la misma línea se expresó Requejo Rodríguez con ocasión del estado de alarma declarado el 4 de diciembre de 2010, para quien la naturaleza jurídica de los decretos de declaración y de prórroga del estado de alarma sería la de disposición reglamentaria en ambos casos, sin que la intervención del Congreso, recibiendo primero una mera comunicación del Gobierno o autorizando después la prórroga, suponga una elevación del rango normativo de los decretos que formalizan tanto la declaración como la prórroga ${ }^{19}$.

Por su parte, Parada Vázquez, y antes Carro Fernández-Valmayor y GómezFerrer Morant, caracterizaron a los decretos de declaración y de prórroga del estado de alarma como reglamentos u ordenanzas de necesidad, considerando por tales aquellos reglamentos sui generis que, en palabras de Parada, "no necesitan de procedimiento de elaboración y no derogan las normas legales que contradicen, sino que suspenden su vigencia mientras dura la situación de emergencia", características estas que "unidas a la circunstancia de que [las medidas] caducan por sí mismas sin quedar injertadas en el ordenamiento tras la situación de emergencia, hace que las medidas que contienen los reglamentos de necesidad se asemejen más a los actos generales que a los verdaderos reglamentos" ${ }^{20}$. E idéntica caracterización ha realizado Villar Crespo atendiendo a la provisionalidad de los decretos de declaración y de prórroga, a la inaplicabilidad del procedimiento de elaboración de reglamentos en su gestación y a la capacidad de dichos decretos para suspender o

18 CRUZ VILLALÓN, P., "EI nuevo derecho de excepción", cit., pp. 115-116, y LAFUENTE BALLE, J. M., "Los estados de alarma, excepción y sitio (II)", Revista de Derecho Político, núm. 31,1990, pp. 34 y 42.

${ }^{19}$ REQUEJO RODRÍGUEZ, P., "Teoría vs. práctica del estado de alarma en España", en VV. AA., Constitución y democracia: ayer y hoy. Libro homenaje a Antonio Torres del Moral, vol. 2, Universitas, Madrid, 2012, pp. 1512-1513.

${ }^{20}$ PARADA VÁZQUEZ, R., Derecho Administrativo, vol. I, 24를. ed., Open, Madrid, 2014, p. 65. Asimismo, CARRO-VALMAYOR, J. L. y GÓMEZ-FERRER MORANT, R., "La potestad reglamentaria del Gobierno y la Constitución", Revista de Administración Pública, núm. 87, 1978, p. 198. 
excepcionar la aplicación de leyes y disposiciones normativas con rango de ley durante la vigencia del estado de alarma, razón por la cual, pese a su naturaleza reglamentaria sui generis, el control de dichos decretos debía ser, en todo caso, un control de legalidad y corresponder a la jurisdicción contencioso-administrativa $^{21}$.

\section{Los decretos de declaración y de prórroga del estado de alarma como actos con fuerza de ley reservados al control de la justicia constitucional}

Las decisiones que el ordenamiento atribuye al Gobierno como titular de la potestad reglamentaria del Estado se formalizan mediante decretos. Pero no todas las decisiones jurídico-públicas adoptadas a través de decretos son expresión de esa potestad, necesariamente sometida a los principios de legalidad y jerarquía normativa. Los decretos son un instrumento jurídico que, al igual que las leyes, puede tener un contenido muy diverso y servir para formalizar decisiones de muy distinto rango procedentes, además, de una pluralidad de órganos constitucionales, puesto que el rey expide decretos a propuesta del Gobierno, como señala el artículo 62.f) de la CE, pero también a propuesta del Congreso de los Diputados, del Senado, del Consejo General del Poder Judicial, del Tribunal Constitucional y de las Asambleas legislativas de las Comunidades Autónomas.

El nombramiento del presidente del Gobierno [arts. 62.d), 99 o 113 de la CE], la disolución automática de las Cortes en los supuestos de reforma constitucional agravada (art. 168 de la CE) o de incapacidad para lograr la investidura presidencial (art. 99.5 de la CE) y el nombramiento de magistrados del Tribunal Constitucional y de diez vocales del Consejo General del Poder Judicial a propuesta de ambas cámaras (arts. 159.1 y 122.3 de la CE y 112 de la LOPJ, respectivamente) son decisiones formalizadas por decreto, en unos casos refrendadas por el presidente del Congreso de los Diputados y en otros por el ministro de Justicia. Forma de decreto adoptan también el nombramiento o cese de los miembros del Gobierno [arts. 62.e) y 100 de la CE], la disolución anticipada de las Cortes Generales y la convocatoria de elecciones generales y

\footnotetext{
${ }^{21}$ VILLAR CRESPO, G., "Comentario a la STC 83/2016: con motivo de la naturaleza de los decretos del Gobierno que declaran el estado de alarma", Revista General de Derecho Administrativo, núm. 48, 2018, pp. 25-27. Disponible en: https://www.iustel.com//v2/revistas/detalle_revista.asp?id_noticia=420390\&\#nota75.
} 
de referéndum consultivo (arts. 115 y 92 de la CE), que no son decisiones acordadas en Consejo de Ministros sino potestades constitucionales de su presidente, por lo que no constituyen expresión de la potestad reglamentaria gubernamental. Lo mismo ocurre con otras resoluciones que sí son del Gobierno y deben adoptar la forma jurídica de decretos, pero que, como señala el artículo 24.1.c) de la Ley 50/1997, de 27 de noviembre, del Gobierno (LG), no son normas reglamentarias y su procedimiento de elaboración es distinto al previsto en el artículo 26 de la $\mathrm{LG}^{22}$. Este último sería el caso de los decretos de declaración y de prórroga del estado de alarma, cuya aprobación, junto con los decretos de declaración y de prórroga del estado de excepción, se atribuye al Consejo de Ministros en el artículo 5.1 de la LG en letra distinta a la que le atribuye la facultad para aprobar reglamentos de desarrollo y ejecución de las leyes, previo dictamen del Consejo de Estado (letras fy $h$, respectivamente).

Formalizadas mediante decretos, dichas decisiones gubernamentales de declaración y de prórroga de alarma y de excepción nada tienen que ver, por su incidencia constitucional, con la definición de potestad reglamentaria que contiene el artículo 128 de la Ley 39/2015, de 1 de octubre, del procedimiento administrativo común de las Administraciones Públicas (LPACAP), cuyo párrafo 2 señala que los reglamentos no podrán vulnerar leyes, ni "podrán tipificar delitos, faltas o infracciones administrativas, establecer penas o sanciones, así como [...] prestaciones personales o patrimoniales de carácter público", extremos que -a excepción de la tipificación de delitos y faltas y la fijación de penas- sí pueden contener, en cambio, los referidos decretos de declaración y de prórroga de los estados de alarma y de excepción al amparo de la LOAES. La CE y la LOAES, al prever la formalización de estas decisiones excepcionales mediante decretos, no incurrieron, por tanto, "en un claro defecto de técnica legislativa que, de algún modo, [...] subvierte la regulación teórica del sistema de producción de normas ${ }^{23}$, sino que optaron por un instrumento jurídico susceptible de contenidos y rangos diversos para expresar decisiones jurídico-públicas no infraordenadas a la ley, sino a la propia Constitución.

\footnotetext{
Sobre la diversidad de los decretos en nuestro sistema constitucional, IGLESIA CHAMARRO, Má. A. DE LA: El Gobierno por decreto, Ediciones Universidad de Navarra, Pamplona, 1997, págs. 136-174.

${ }^{23}$ MATEU-ROS Y CEREZO, R., "Crisis del Estado y fuentes del Derecho", en VV.AA., La Constitución española y las fuentes del Derecho, vol. II, Instituto de Estudios Fiscales, Madrid, 1979, pp. 1399-1400.
} 
Persuadido de ello, Alzaga Villaamil subrayó que los decretos de declaración y de prórroga de los estados de alarma y de excepción serían un tertium genus distinto tanto de los decretos ordinarios como de los decretos legislativos ${ }^{24}$. Y no fue el único autor. Aragón Reyes y Navas Castillo caracterizaron los decretos de prórroga del estado de alarma y de declaración y prórroga del estado de excepción como actos del Estado con fuerza de ley de los previstos, con finalidad procesal, en el artículo 27.2.b) de la LOTC, naturaleza que en su opinión sería predicable de los decretos de incidencia constitucional en los que las Cortes Generales o una de sus cámaras, como es el caso, intervienen en su procedimiento de adopción, lo que justificaría su control ante el $\mathrm{TC}^{25}$. Sin ser formalmente leyes, dichos decretos excepcionales dispondrían de sus mismas características materiales y procedimentales. Serían, al igual que las leyes, expresión de la voluntad parlamentaria que se alcanza mediante un procedimiento garantista. Con la expresión "acto con fuerza de ley", se privilegiarían, en palabras de Navas Castillo, "las garantías democráticas que cumple ese acto [...] que emana del Parlamento, como consecuencia de un procedimiento pluralista y garantista de elaboración sin que sea, sin embargo, una ley formal ${ }^{26}$. Fuera de la categoría de actos con fuerza de ley quedarían, sin embargo, según esta tesis, los decretos de declaración del estado de alarma en cuya adopción, que corresponde en exclusiva al Gobierno, no interviene el Congreso de los Diputados. Debido a ello, ambos autores consideraron que dichos decretos no trascienden su condición formal y tienen la naturaleza jurídica de las disposiciones reglamentarias sometidas a la jurisdicción contencioso-administrativa. Lo que no deja de resultar paradójico porque, si el decreto de prórroga del estado de alarma tiene fuerza de ley y debe ser controlado por el TC, como han sostenido ambos autores, ¿puede en puridad el decreto de declaración del que trae causa ser un mero reglamento previendo idénticas excepciones, suspensiones o modificaciones temporales del ordenamiento jurídico que aquel?

\footnotetext{
24 ALZAGA VILLAAMIL, O., Comentario sistemático a la Constitución española de 1978, Ediciones del Foro, Madrid, 1978, p. 699.

${ }^{25}$ ARAGÓN REYES, M., "Acto con fuerza de ley", en ARAGÓN REYES, M. (coord.), Temas básicos de Derecho Constitucional, tomo I, Civitas, Madrid, 2001, p. 342 y NAVAS CASTILLO, A., "Los estados excepcionales y su posible control por el Tribunal Constitucional", cit., pp. 158163.

${ }^{26}$ NAVAS CASTILLO, A., El control jurisdiccional de los actos parlamentarios sin valor de ley, Colex, Madrid, 2000, p. 47.
} 
Otra doctrina consideró que la fuerza de ley de determinados actos o decisiones no tendría que ver con la participación parlamentaria en su adopción, sino con su condición de complemento imprescindible para la plena efectividad de ciertos preceptos constitucionales o para la validez de normas jurídicas con rango de ley, independientemente de su procedencia parlamentaria o exclusivamente gubernamental. Porres Azkona atribuyó fuerza de ley a los actos de aplicación inmediata de la Constitución ${ }^{27}$. En el mismo sentido, Mateu-Ros, incluso antes de que la expresión "actos con fuerza de ley" fuera incorporada a la LOTC, afirmó que la "fuerza normativa" de determinados actos deriva de su capacidad para innovar o modificar, siquiera provisionalmente, el ordenamiento jurídico en base a una habilitación constitucional expresa, lo que los hace controlables a través de la misma instancia prevista para enjuiciar la conformidad de las leyes y disposiciones normativas con fuerza de ley respecto de la Constitución ${ }^{28}$. García Cuadrado, por su parte, atribuyó la cualidad de actos constitucionales con fuerza de ley a aquellas decisiones políticas jurídicamente formalizadas que tienen un contenido singular y concreto y que, por su carácter primario y directamente infraordenado a la Constitución, tienen una eficacia similar o equivalente a una ley. Dicha eficacia o "fuerza" no significa que tengan capacidad para derogar leyes, capacidad que en rigor ya no tienen muchas leyes respecto de otras. Tener fuerza de ley ex artículo 27.2.b) de la LOTC implicaría, a su juicio, quedar exento del control de legalidad que ejercen los tribunales ordinarios, porque dichos actos "realizan" directamente un precepto constitucional o le proporcionan el complemento necesario para que pueda "realizarse". Y porque están, como las leyes, directamente incardinados en la Constitución y presentan su mismo carácter primario, incluso cuando una ley pueda complementar los preceptos constitucionales que regulan su emisión ${ }^{29}$. Dichas decisiones no son propiamente normas, porque no contienen mandatos generales y abstractos que se incorporen al ordenamiento jurídico. Tampoco son actos administrativos, porque ni su contenido ni la competencia de su titular están legalmente reglados, sino "constitucionalmente" reglados. Pero tienen

${ }^{27}$ PORRES AZKONA, J., "La decisión sobre poderes excepcionales", Revista Vasca de Administración Pública, núm. 6, 1983, pp. 47-48.

${ }_{28}^{28}$ MATEU-ROS Y CEREZO, R., "Crisis de Estado y fuentes del Derecho", cit., p. 1398.

29 GARCÍA CUADRADO, A. M., "Aproximación a una teoría de los «actos constitucionales»", Revista de Derecho Político, núm. 46, 1999, pp. 44-49, y, del mismo autor, "Los actos parlamentarios con fuerza de ley", Corts. Anuario de Derecho Parlamentario, núm. 7, 1999, pp. 280-287. 
valor de ley y, por ello, el control de dichos actos debe reservarse al Tribunal Constitucional mediante recurso directo o cuestión de inconstitucionalidad.

Caracterizada la categoría en estos términos, los decretos de declaración y de prórroga de los estados de alarma y de excepción podían considerarse, a juicio de Porres Azkona, actos del Estado con fuerza de ley que realizan o desarrollan inmediatamente el artículo 116 de la CE, por lo que no cabría sobre ellos un juicio de legalidad sino de constitucionalidad ${ }^{30}$. En el mismo sentido se pronunció Aparicio Pérez, para quien el Gobierno está habilitado constitucionalmente para dictar los decretos de declaración y de prórroga de ambos estados, por lo que su control sólo podía ser atribuido al Tribunal Constitucional $^{31}$. Dichos decretos, sostuvo también García Cuadrado, son el complemento necesario para la plena efectividad del derecho constitucional de excepción, normalmente inactivo o latente. Los decretos excepcionales constatan y declaran la emergencia, determinando al tiempo las medidas a adoptar, que alteran el estatuto ordinario del poder, limitan derechos e imponen obligaciones y deberes extraordinarios. Son decisiones singulares y concretas directamente infraordenadas a la Constitución, pero también son fuente de habilitación y canon de legalidad para las disposiciones y actos administrativos dictados por la autoridad competente bajo la vigencia del estado declarado. No son propiamente normas que se incorporen al ordenamiento, sino actos, pero tienen fuerza ley, porque singular y temporalmente ocupan ex Constitutione "el lugar de una verdadera norma a la hora de enjuiciar la validez y legalidad de los actos administrativos que se dictan apoyándose en la declaración” ${ }^{32}$. Y debido a ello, a su carácter primario y esencialmente constitucional, el control de dichos actos no debe ser residenciado ante los tribunales contenciosoadministrativos, sino ante el Tribunal Constitucional, a quien corresponderá determinar si los decretos de declaración y de prórroga han respetado o no los requisitos materiales y formales exigidos por la CE y la LOAES para declarar y prorrogar el estado de alarma o para modificar sus condiciones ${ }^{33}$.

\footnotetext{
${ }^{30}$ PORREZ AZKONA, J., "La decisión sobre poderes excepcionales”, cit., p. 48.

31 APARICIO PÉREZ, M. A., "¿Hacia una nueva figura de actos políticos del Gobierno?”, en VV.AA., El Gobierno en la Constitución española y en los Estatutos de Autonomía, Diputación de Barcelona, Barcelona, 1985, p. 193.

32 GARCíA CUADRADO, A. M., "Aproximación a una teoría de los «actos constitucionales»", cit., p. 52.

${ }^{33}$ GARRIDO LÓPEZ, C., "Sobre la naturaleza jurídica de la declaración de los estados excepcionales previstos en el artículo 116 de la CE y su control jurisdiccional", en VV.AA.,
} 


\section{III.EL PROBLEMA DEL CONTROL JURISDICCIONAL DE LOS DECRETOS DE DECLARACIÓN Y DE PRÓRROGA DEL ESTADO DE ALARMA ANTE EL TRIBUNAL SUPREMO Y EL TRIBUNAL CONSTITUCIONAL}

Durante décadas, ningún estado de alarma fue declarado. Los graves incendios forestales, las afecciones de servicios públicos esenciales y las catástrofes medioambientales, como la del Prestige, fueron afrontados por las autoridades con las medidas previstas en la Ley $2 / 1985$, de 21 de enero, de Protección Civil y en otras leyes sectoriales (entre ellas, la Ley 81/1968, de 5 de diciembre, de Incendios Forestales; la Ley 38/1972, de 22 de diciembre, de Protección del Ambiente Atmosférico; Ley 20/1986, de 14 de mayo, Básica de Residuos Tóxicos y Peligrosos; la Ley Orgánica 3/1986, de 14 de abril, de Medidas Especiales en Materia de Salud Pública; la Ley 33/2011, de 4 de octubre, General de Salud Pública, etc.), así como en el artículo 15.3 de la Ley Orgánica 5/2005, de 17 de noviembre, de la Defensa Nacional, que prevé la intervención de las Fuerzas Armadas en situaciones "de grave riesgo, catástrofe, calamidad u otras necesidades públicas”, y al amparo del Protocolo de intervención de la Unidad Militar de Emergencias (UME), aprobado por Real Decreto 1097/2011, de 22 de julio. Los supuestos habilitantes del artículo 4 de la LOAES concurrieron en numerosas ocasiones, pero el estado de alarma quedó inédito.

La situación cambió, sin embargo, drásticamente a finales de 2010 cuando, tras un largo conflicto laboral entre los controladores civiles de tránsito aéreo y la entidad pública empresarial Aeropuertos Españoles y Navegación Aérea (AENA), la tarde del 3 de diciembre cientos de controladores abandonaron sus puestos de trabajo en las torres y centros de control $^{34}$. A resultas de este boicot, el espacio aéreo español tuvo que ser cerrado y cientos de vuelos

Estudios sobre la Constitución Española: homenaje al profesor Jordi Solé Tura, vol. 2, Cortes Generales y Centro de Estudios Políticos y Constitucionales, Madrid, 2008, pp. 1248-1253.

${ }^{34}$ Tras meses de tensas negociaciones entre los controladores civiles de tránsito aéreo, AENA y el Ministerio de Fomento, el Gobierno aprobó el Real Decreto-ley 13/2010, de 3 de diciembre, cuya disposición adicional segunda ratificaba la jornada laboral aprobada en el Decreto 1001/2010, de 5 de agosto, y apelaba a AENA para facilitar lo dispuesto en el artículo 4.4.a) de la Ley de Seguridad Aérea, quedando sometidos los controladores de tránsito aéreo a la dirección del Ministerio de Defensa, quien asumiría su organización, planificación, supervisión y control. Esa misma tarde, cientos de controladores abandonaron sus puestos de trabajo alegando el supuesto de incapacidad psicológica previsto en la Ley de Seguridad Aérea, lo que desencadenó el caos aeroportuario. Sobre este conflicto laboral, véase VIDAL PRADO C. y DELGADO RAMOS, D., "Algunas consideraciones sobre la declaración del estado de alarma y su prórroga", Revista Española de Derecho Constitucional, núm. 92, 2011, pp. 243-247. 
fundación

Manuel Giménez Abad

deEstudios Parlamentarios ydelEstado Autonómico

fueron suspendidos, viéndose afectados miles de viajeros. Ante esta situación, el Gobierno encomendó al jefe del Estado Mayor del Ejército del Aire las facultades de control de tránsito aéreo atribuidas a AENA al amparo del artículo 4.4.a) de la Ley 21/2003, de 7 de julio, de Seguridad Aérea, en una suerte de "militarización" operativa del servicio que no surtió efecto debido a la imposibilidad de la autoridad militar para impartir órdenes de obligado cumplimiento a los controladores civiles. Y debido a ello, el Gobierno decidió, por primera vez en nuestro país, declarar el estado de alarma mediante el Real Decreto 1673/2010, de 4 de diciembre [BOE núm. 295, de 4 de diciembre (extraordinario)], cuyo artículo 3 atribuyó a los controladores la consideración de personal militar, quedando sometidos a las órdenes de las autoridades militares y a las leyes penales y disciplinarias militares. La normalidad fue restablecida merced a esta medida, pero, ante el riesgo de que la situación se repitiera durante las vacaciones de Navidad, el Gobierno, tras obtener la autorización del Congreso de los Diputados, prorrogó el estado de alarma en sus mismos términos hasta el 15 de enero de 2011 mediante el Real 1717/2010, de 17 de diciembre (BOE núm. 307, de 28 de diciembre de 2010).

Los controladores afectados decidieron impugnar los decretos de declaración y de prórroga del estado de alarma e iniciaron un largo conflicto judicial que dio lugar a siete autos del Tribunal Supremo de inadmisión de sendos recursos contencioso-administrativos, a un auto del Tribunal Constitucional, que inadmitió un recurso de amparo presentado contra la autorización parlamentaria de la prórroga y, finalmente, a la importante STC 83/2016, de 28 de abril, en la que el Pleno desestimó el recurso de amparo interpuesto contra el ATS 5696/2011, de 30 de mayo, por una supuesta vulneración de la tutela judicial efectiva, al haber negado la revisión jurisdiccional de los decretos de declaración y de prórroga del estado de alarma.

Diez años después de la primera declaración del estado de alarma, el Gobierno se ha visto abocado a una nueva declaración a fin de contener la expansión de los contagios provocados por el coronavirus covid-19 y evitar el colapso del sistema sanitario. El Real Decreto 463/2020, de 14 de marzo (BOE núm. 67, de 14 de marzo), restringió sensiblemente la libertad de circulación de las personas por las vías de uso público, autorizó requisas temporales y adoptó una amplia batería de medidas para reforzar el Sistema Nacional de Salud, asegurar el suministro de bienes y servicios necesarios para la protección de la salud pública, evitar el desabastecimiento alimentario y limitar el trasporte 
interior y el trasporte aéreo a los servicios mínimos esenciales compatibles con las exigencias de salud pública. Y, dada la naturaleza e intensidad de la crisis sanitaria, el estado de alarma fue prorrogado en seis ocasiones por períodos de quince días hasta el 21 de junio de $2021^{35}$.

Disconformes con la severa restricción de la libertad deambulatoria y la afección de otros derechos conexos, como los de reunión, manifestación y libertad de cultos, varios ciudadanos presentaron ante la jurisdicción contencioso-administrativa sendos recursos contra los decretos de declaración y de prórroga por el cauce especial de protección de los derechos fundamentales de la persona, que fueron inadmitidos alegando falta de jurisdicción por la Sala Tercera del Tribunal Supremo. Y, aunque habían celebrado la declaración del estado de alarma y votado a favor de la primera prórroga, los diputados del Grupo Parlamentario Vox interpusieron el 28 de abril de 2020 un recurso de inconstitucionalidad contra los Reales Decretos 463/2020, de 14 de marzo, de declaración, y 476/2020, de 27 de marzo, y $487 / 2020$, de 10 de abril, de primera y segunda prórroga, a resultas del cual el Tribunal Constitucional deberá dictar sentencia pronunciándose sobre la naturaleza de dichos decretos y su fiscalización jurisdiccional. Y no será la última vez, porque el 6 de noviembre de 2020, 51 diputados del mismo Grupo Parlamentario presentaron un nuevo recurso de inconstitucionalidad, en esta ocasión contra el Real Decreto 926/2020, de 25 de octubre, por el que se declaró el estado de alarma para contener la propagación de infecciones causadas por el SARS-CoV-2 y contra varios preceptos del Real Decreto 956/2020, de 3 de noviembre, de prórroga de dicho estado de alarma.

\section{La autorización parlamentaria de la prórroga como causa de la falta de jurisdicción del Tribunal Supremo sobre los decretos de declaración y de prórroga del estado de alarma de 2010}

Los controladores aéreos incluidos en el ámbito personal de aplicación del estado de alarma declarado y prorrogado en diciembre de 2010 consideraron que no concurrían los supuestos legales de dicho estado; que su militarización

\footnotetext{
${ }^{35}$ Reales Decretos 476/2020, de 27 de marzo (BOE núm. 86, de 28 de marzo), 487/2020, de 10 de abril (BOE núm. 101, de 11 de abril), 492/2020, de 24 de abril (BOE núm. 115, de 25 de abril), 514/2020, de 8 de mayo (BOE núm. 129, de 9 de mayo), 537/2020, de 22 de mayo (BOE núm. 145, de 23 de mayo) y 555/2020, de 5 de junio (BOE núm. 159, de 6 de junio).
} 
vulneraba derechos fundamentales y que la prórroga carecía de justificación ${ }^{36}$. $Y$ atendiendo a su forma jurídica, entendieron que los decretos de declaración y de prórroga eran disposiciones reglamentarias del Gobierno que debían ser controladas por la justicia contencioso-administrativa. En representación de la mayoría del colectivo, la Unión Sindical de Controladores Aéreos (USCA) interpuso dos recursos contencioso-administrativos contra el Real Decreto 1673/2010, de 4 de diciembre, de declaración del estado de alama, y el Real Decreto 1717/2010, de 17 de diciembre, de prórroga, respectivamente. Días después, varios controladores aéreos interpusieron un nuevo recurso contra el Real Decreto de declaración. Y en régimen de litisconsorcio activo necesario, varios cientos de controladores interpusieron, finalmente, un cuarto recurso, en esta ocasión contra el Decreto de declaración, el acuerdo del Consejo de Ministros de 14 de diciembre de 2010 mediante el que se solicitó al Congreso autorización para prorrogar el estado de alarma y el Decreto que lo prorrogó.

Los recursos fueron inadmitidos por el Tribunal Supremo en los AATS 857/2011, de 10 de febrero, y 2985/2011, de 9 de marzo (este último dictado tras un recurso de súplica), AATS 3816/2011, de 5 de abril y 6821/2011, de 8 de junio (el segundo también tras un recurso de súplica) y los AATS 5696/2011 y 5698/2011, de 30 de mayo, el primero de los cuales fue confirmado en reposición por el ATS 6197/2012, de 1 de junio.

\footnotetext{
${ }^{36}$ Esta fue también la opinión en la doctrina de VIDAL PRADO, C. y DELGADO RAMOS, D., "Algunas consideraciones sobre la declaración del estado de alarma y su prórroga", cit., pp. 253-260; ABA CATOIRA, A., "El estado de alarma en España", Teoría y realidad constitucional, núm. 28, 2011, pp. 335-336; REQUEJO RODRÍGUEZ, P., "Teoría vs. práctica del estado de alarma en España", cit., pp. 1502-1506; SEDANO LORENZO, A., El estado de alarma y la justicia militar. A propósito de la crisis de controladores aéreos, Liber Factory, Madrid, 2015, pp. 80-84 y 106-109, y SIEIRA MUCIENTES, S., "Los estados excepcionales", Revista de las Cortes Generales, núm. 104, 2018, pp. 376-380. En contra, sin embargo, se pronunció F. J. ENÉRIZ OLAECHEA, quien sostuvo que concurrieron los presupuestos necesarios para la declaración: el abandono de sus obligaciones por los controladores paralizó un servicio público esencial, no se garantizó lo dispuesto en los artículos 28.2 y 37.2 de la CE y concurrió una catástrofe o calamidad pública de enorme magnitud, interpretados ambos términos en su sentido etimológico, como sucesos infaustos y desgraciados que alcanzan a muchas personas y alteran gravemente el orden regular de las cosas. Cfr. "La declaración del estado de alarma para la normalización del transporte aéreo". Cfr. Revista Aranzadi Doctrinal, núm 6, 2011, pp. 85-91. También, CARRERAS, F. DE: "Un claro supuesto del estado de alarma", La Vanguardia, 5 de diciembre de 2010, y BALAGUER CALLEJÓN, F., "El colectivo Eyjafjalla", Público, 8 de diciembre de 2010, y, por lo que respecta a la militarización, que consideró conforme a Derecho, véase JIMÉNEZ VILLAREJO, J., "La militarización de los controladores". El País, 13 de diciembre de 2010 (disponible en http://elpais.com/diario/2010/12/13/opinion/1292194804_850215.html).
} 
En los AATS 857/2011, de 10 de febrero, y 2985/2011, de 9 de marzo, el TS subrayó la doble condición del Gobierno a la que las SSTC 45/1990, de 15 de marzo, 196/1990, de 29 de noviembre, y 220/1991, de 25 de noviembre, se habían referido: "la condición de órgano constitucional que tiene atribuidas unas funciones directamente por la Constitución y no por el Derecho Administrativo, y la de órgano administrativo que dirige la Administración General del Estado; y la consecuencia derivada de lo anterior es que, en cuanto a las actuaciones realizadas desde esa primera condición que acaba de apuntarse, ha de estarse a lo establecido en la Constitución" y su control no podía ser sino de constitucionalidad. Consciente, no obstante, de que incluso los actos del Gobierno en relación con las Cortes regulados en el título V CE podrían ser sometidos a la jurisdicción contencioso-administrativa por lo que respecta a sus elementos reglados, en virtud del artículo 2.1.a) de la Ley 29/1998, de 13 de julio, reguladora de la jurisdicción contencioso-administrativa $(\text { LJCA })^{37}$, el TS añadió que la impugnación se dirigía contra un acto, el de declaración, cuyo contenido había sido asumido en su integridad por el Congreso de los Diputados desde el momento en que este autorizó la prórroga de dicho estado en los mismos términos en que inicialmente fue declarado. " $Y$, por esta razón -afirmó el TS-, esa decisión asumida por la Cámara no es una actuación que pueda ser controlada por este orden contencioso-administrativo; porque está fuera del genérico ámbito delimitado para el control jurisdiccional en el artículo 106.1 CE, y tampoco tiene encaje dentro del concreto ámbito de conocimiento que la jurisdicción contencioso-administrativa delimitan los artículos 1 y 2 LJCA" (ATS 857/2011, de 10 de febrero, razonamiento jurídico 4). Y los mismos argumentos -que "cobran todavía más fuerza en este caso" según el ATS 3816/2011- utilizó el Alto Tribunal para rechazar la revisión de la prórroga, aunque su formalización última se exprese mediante Real Decreto, porque "aquí a la asunción por la Cámara del contenido de la declaración, con lo que esto implica de aceptación de su necesidad y regularidad, ha de

\footnotetext{
${ }^{37}$ Con anterioridad a la aprobación de la LJCA, ya hubo pronunciamientos en este sentido, como la STS de 15 de julio de 1997, que anuló la Sentencia del Tribunal Superior de Justicia de Andalucía, con sede en Sevilla, argumentando que el decreto autonómico de disolución de la Asamblea legislativa y de convocatoria de elecciones que aquel se había negado a enjuiciar era un acto de Gobierno que podía ser controlado en sus elementos estatutariamente reglados. No obstante la singular naturaleza del decreto, infraordenado a la CE y al Estatuto de autonomía, "[...] debemos aceptar -subrayó el Tribunal Supremo- el examen de las eventuales extralimitaciones o incumplimientos de los requisitos previos en que el Gobierno hubiera podido incurrir al tomar la decisión".
} 
añadirse que la prórroga no es constitucionalmente posible sin dicha autorización".

El sindicato USCA recurrió en reposición aduciendo que el Congreso autorizó la prórroga, no la declaración, pero el ATS 2985/2011 subrayó que, al autorizar la prórroga y mantener las mismas condiciones con que el estado de alarma fue declarado, el Congreso de los Diputados asumió "como decisión propia esa inicial declaración y, por tanto, le dio naturaleza y carácter parlamentario. Es claro, pues, que no se está ya ante una actuación del Gobierno sino ante una resolución de la Cámara ejercitando una de las funciones que la Constitución le atribuye, como también lo es que esta resolución, está fuera [...] del concreto ámbito de conocimiento de la jurisdicción contencioso-administrativa que delimitan los artículos 1 y 2 LJCA" (fundamento jurídico 3). Y en los mismos términos se pronunció el ATS 6821/2011, de 8 de junio, que resolvió el recurso de súplica presentado contra el ATS 3816/2011, de 5 de abril.

Para negar, en suma, a los decretos de declaración y de prórroga del estado de alarma la condición de actos del Gobierno susceptibles de ser revisados por la jurisdicción contencioso-administrativa, el TS otorgó a la autorización parlamentaria de la prórroga la capacidad de alterar la naturaleza jurídica tanto del decreto de prórroga como del decreto de declaración. El problema de esta tesis, a nuestro juicio, es que la declaración del estado de alarma no altera su naturaleza ni se "parlamentariza" porque el Gobierno solicite y obtenga, en su caso, autorización del Congreso para prorrogar el estado declarado. La autorización parlamentaria permite al Gobierno prorrogar dicho estado, pero no "ratifica la validez" de su declaración, porque esa declaración, de concurrir los supuestos de hecho habilitantes, ya es válida y posee plena eficacia jurídica independientemente de la autorización parlamentaria de su prórroga posterior, si es que ésta se produce, y al margen de los términos de la misma.

\section{La consideración de los decretos de declaración y de prórroga de $\mathbf{2 0 1 0}$ como actos con fuerza de ley por la STC 83/2016, de 28 de abril, dictada a resultas de un proceso de amparo}

La inadmisión mediante el ATS 5696/2011, de 30 de mayo, confirmado en reposición por el ATS 6197/2012, de 1 de junio, del recurso contenciosoadministrativo interpuesto contra los decretos de declaración y de prórroga del estado de alarma fue recurrida en amparo ante el Tribunal Constitucional por 
327 controladores aéreos, quienes fundamentaron su demanda en la violación del derecho a la tutela judicial efectiva en su vertiente de derecho de acceso a la jurisdicción, en la medida en que las resoluciones judiciales citadas habían impedido que recayera una sentencia de fondo sobre la concurrencia de los presupuestos habilitantes para proceder a la declaración y la prórroga del estado de alarma y sobre la vulneración de sus derechos. A juicio de los recurrentes, los reales decretos de declaración y de prórroga del estado de alarma impugnados en la vía judicial tenían la naturaleza de disposiciones administrativas plenamente fiscalizables por la jurisdicción contenciosoadministrativa, sin que pudiera considerárseles decisiones o actos políticos o de gobierno. Y sin que la autorización del Congreso de los Diputados exigida para la prórroga hubiera, en su opinión, modificado o transformado su naturaleza reglamentaria.

El Pleno del TC avocó para sí la resolución del recurso debido a la trascendencia constitucional que revestía la caracterización jurídica de los decretos de declaración y de prórroga del estado de alarma, con la consiguiente delimitación en nuestro ordenamiento de los ámbitos propios de la jurisdicción ordinaria y de la jurisdicción constitucional. $Y$ asumiendo los argumentos contenidos en el ATC 7/2012, de 13 de enero, que se había pronunciado sobre la autorización parlamentaria de la prórroga del estado de alarma impugnada en amparo por la vía del artículo 42 de la LOTC ${ }^{38}$, el TC sostuvo la existencia en nuestro sistema de fuentes de ciertas decisiones que sin ser leyes o fuentes equiparadas a la ley, podían, conforme a la propia Constitución, afectar a aquellas normas legales o asimiladas, esto es, excepcionarlas, suspenderlas o modificar su aplicabilidad. Con las expresiones "fuerza" o "valor" de ley, subrayó el TC en el fundamento jurídico 9 de la STC 83/2016, la CE primero, y luego la LOTC, quisieron "acotar un genus de normas, decisiones y actos, del que serían especificaciones, además de la propia ley parlamentaria, otras fuentes en parte equiparadas a la misma por la propia Constitución, así como algunos actos, decisiones o resoluciones no identificados como tales ni en la Constitución ni en la LOTC, pero que sí gozarían de aquel «valor» o «rango», en virtud del cual no serían

${ }^{38}$ Sobre el ATC 7/2012 véanse CONTRERAS CEREZO, P. V., "El estado de alarma: controladores aéreos", Diario La Ley, núm. 7881, 2012, pp. 4-14 y ALEGRE ÁVILA, J. M., "Una nota a propósito de los estados de alarma, excepción y sitio: la declaración gubernamental como acto político y la autorización/declaración parlamentaria como acto sin valor de ley", Revista española de Derecho Administrativo, núm. 163, 2014, pp. 339-352. 
residenciables ante el Tribunal Constitucional por la vía del recurso de amparo. [...] y sólo cabría impugnarlos ante este Tribunal a través de los procesos constitucionales previstos en la Constitución y en la LOTC que tienen por objeto el control de constitucionalidad de las leyes, normas y actos con fuerza 0 valor de ley (FJ 3)" (STC 83/2016, fundamento jurídico 9).

A esta categoría pertenecerían claramente, según el TC, los decretos de declaración y de prórroga del estado de alarma, que no adoptan la forma de ley pero configuran el régimen jurídico del estado de emergencia declarado 0 prorrogado. Estos decretos no se limitan a declarar la emergencia, ni a constatar la concurrencia de alguna o algunas de las situaciones excepcionales previstas en el artículo 4 de la LOAES, sino que vienen a integrar en cada caso, sumándose a la CE y a la LOAES, el sistema de fuentes del derecho de excepción, al precisar sus previsiones para el estado declarado. La legalidad excepcional que contiene el decreto de declaración, afirma el TC, "desplaza durante el estado de alarma la legalidad ordinaria en vigor, en la medida en que viene a excepcionar, modificar o condicionar durante ese periodo la aplicabilidad de determinadas normas, entre las que pueden resultar afectadas leyes, normas o disposiciones con rango de ley, cuya aplicación puede suspender o desplazar" (STC 83/2016, fundamento jurídico 10). Aunque formalizada mediante decreto, la decisión de declarar el estado de alarma está directamente incardinada en la Constitución y, dado su contenido y efectos, posee un valor equiparable al de las leyes. Es, en suma, un acto o resolución con fuerza y valor de ley, aunque en su gestación no haya intervenido el Congreso de los Diputados, porque dicha fuerza y valor no se deriva de la condición parlamentaria o gubernamental del titular de la decisión, sino de sus efectos excepcionales sobre el ordenamiento jurídico.

E idéntica conclusión, por las mismas razones, alcanzó el TC en relación con la naturaleza jurídica del decreto de prórroga del estado de alarma. A diferencia del decreto de declaración, el decreto de prórroga formaliza y exterioriza el acuerdo parlamentario de autorización, pero el rango y la fuerza de ley que posee para incidir sobre la legalidad no deriva de esa intervención parlamentaria previa, sino, como ocurre con el decreto de declaración, de su propia eficacia y fuerza para suspender, exceptuar o modificar durante el período de prórroga la aplicabilidad de ciertas leyes. 
Los AATS que inadmitieron los recursos contencioso-administrativos contra los decretos de declaración y de prórroga del estado de alarma no habían vulnerado, por tanto, el derecho a la tutela judicial efectiva de los controladores aéreos en su vertiente de acceso a la jurisdicción (art. 24.1 CE), al quedar ambos, en razón de su posición en el sistema de fuentes, excluidos del ámbito de fiscalización de la jurisdicción ordinaria. Ello no implica, sin embargo, a juicio del TC, que los decretos de declaración y de prórroga sean inmunes a todo control jurisdiccional, como sostenían los recurrentes, sino que, al poseer rango y valor de ley, sólo cabe impugnarlos ante la jurisdicción constitucional mediante el recurso y la cuestión o autocuestión de inconstitucionalidad [arts. 161 y 163 CE; art. 27.2.b) y 55.2 LOTC], sin perjuicio, como se subraya el fundamento jurídico 11, de que los actos y disposiciones dictados en aplicación de dichos decretos puedan ser revisados por la jurisdicción ordinaria en cada caso competente (art. 3.2 LOAES) y que, agotada la vía judicial, las personas afectadas puedan, asimismo, interponer recurso de amparo contra dichos actos cuando los estimen lesivos de sus derechos fundamentales (art. 43 LOTC) ${ }^{39}$.

\section{Los decretos de declaración y de prórroga del estado de alarma de 2020 ante el Tribunal Supremo: de nuevo la tesis de la intervención parlamentaria como causa de la falta de jurisdicción y la conjetura sobre su doble naturaleza jurídica}

En la STC 83/2016, el Tribunal Constitucional delimitó los ámbitos de la jurisdicción ordinaria y de la jurisdicción constitucional en relación con los decretos de declaración y prórroga del estado de alarma, pero lo hizo a resultas de un recurso de amparo y no como tribunal de control de constitucionalidad, por lo que, al menos formalmente, su pronunciamiento no tenía los efectos atribuidos en el artículo 38 de la LOTC a las sentencias dictadas en los procedimientos de inconstitucionalidad. No resulta extraño, por ello, que la cuestión volviera a plantearse en la primavera de 2020, con ocasión del estado de alarma para la gestión de la crisis sanitaria ocasionada por la covid-19, cuyo

\footnotetext{
${ }^{39}$ Comentaron esta STC en la doctrina, ÁLVAREZ VÉLEZ, Mํ. I., "Sistema de fuentes del Derecho y estado de alama: la STC 83/2016, de 28 de abril", Asamblea. Revista parlamentaria de la Asamblea de Madrid, núm. 34, 2016, pp. 330-337; VILLAR CRESPO, G., "Comentario a la STC 83/2016: con motivo de la naturaleza de los decretos del Gobierno que declaran el estado de alarma", cit., pp. 27-36, y GARRIDO LÓPEZ, C., "Naturaleza jurídica y control jurisdiccional de las decisiones constitucionales de excepción", Revista Española de Derecho Constitucional, núm. 110, 2017, pp. 65-71.
} 
fundación

Manuel Giménez Abad

deEstudios Parlamentarios ydelEstado Autonómico

decreto de declaración y sus primeros decretos de prórroga fueron impugnados ante el TS por el cauce procesal del procedimiento especial de protección de los derechos fundamentales de la persona, al estimar los recurrentes que dichos decretos eran, desde el punto de vista formal, disposiciones reglamentarias y, desde el punto de su contenido, "lesivos del derecho fundamental a la libertad de circulación reconocida en el artículo 19 de la CE y de las garantías de los derechos fundamentales en ella reconocidos".

En el ATS 2505/2020, de 6 de mayo, del que fue ponente la magistrada M‥ del Pilar Teso Gamella, el TS inadmitió el primero de los recursos por falta de jurisdicción tras subrayar que, si bien la Sala Tercera conoce, exartículo 12.1.a) de la LJCA, de las impugnaciones contra las disposiciones de carácter general del Consejo de Ministros que adopten la forma de reales decretos, "no toda actuación del Gobierno, cuyas funciones se enuncian en el artículo 97 del de la CE, está sujeta al Derecho Administrativo (artículo 1.1 de la LJCA), y este es uno de estos casos, atendida la intervención del Congreso de los Diputados, reunido inmediatamente al efecto exartículo 116.2 de la CE. [...] y toda vez que sólo puede prorrogarse con autorización expresa del Congreso de los Diputados, ante el que rinde cuentas el Gobierno, que podrá establecer el alcance y las condiciones vigentes durante la prórroga" (fundamento de derecho $2^{\circ}$ ). Lo decisivo, con todo, para la inadmisión del recurso, y así lo subraya en esta ocasión el TS, son los singulares efectos jurídicos anudados a los decretos de declaración y de prórroga, que no se limitan a constatar la concurrencia del presupuesto de hecho habilitante y su continuidad, sino que desplazan durante su vigencia la legislación ordinaria en vigor "en la medida en que vienen a excepcionar, modificar o condicionar durante ese período la aplicabilidad de determinadas normas, entre las que pueden resultar afectadas leyes, normas o disposiciones con rango de ley", como la STC 83/2016 había señalado. $Y$ revestidos de un valor equiparable, por su contenido, al de las leyes, el orden contencioso-administrativo carece de jurisdicción para conocer de las pretensiones deducidas contra dichos decretos, lo que no equivale a una inmunidad jurisdiccional, sino "que, al poseer ese rango y valor de ley, la impugnación ha de ajustarse al régimen previsto por nuestro ordenamiento jurídico, en lo que afecta a la posición de los órganos de la jurisdicción contencioso-administrativa, para las normas con rango de ley" (fundamentos de derecho 4ㅇ y 5º). En el mismo sentido se pronunció el ATS 2529/2020, de 12 de mayo, cuyo ponente fue el magistrado Pablo $\mathrm{M}^{\mathrm{a}}$. Lucas Murillo de la Cueva. 
Los AATS 2478/2020, de 4 de mayo, y 2508/2020, de 12 de mayo, que tuvieron como ponente al magistrado Jorge Rodríguez-Zapata Pérez, inadmitieron el resto de los recursos contencioso-administrativos interpuestos contra los decretos, pero, a diferencia de los dos Autos anteriores, evidenciaron la reticencia del TS a asumir la caracterización de los decretos de declaración y de prórroga del estado de alarma que había realizado, atendiendo a sus efectos, la STC 83/2016. Una reticencia también compartida por alguna doctrina, que no dudó en sostener la oportunidad del control contenciosoadministrativo de dichos decretos excepcionales. Y cuya opinión se materializó en un dictamen suscrito por cinco catedráticos de Derecho constitucional que uno de los recurrentes presentó en la fase de alegaciones sobre la jurisdicción de la Sala Tercera ${ }^{40}$.

En el dictamen se sostenía el carácter autoaplicativo o directamente aplicable de los decretos impugnados, que respaldaban la imposición de sanciones y vulneraban directamente derechos fundamentales, lo que justificaba su control jurisdiccional al amparo del artículo 2.a) de la LJCA; la necesidad de verificar la compatibilidad de los decretos con las previsiones materiales de la LOAES al amparo de la cual se dictan, porque de no ser así sobrarían cabalmente todos los artículos de la misma; la irrelevancia de la dación de cuenta de la declaración al Congreso de los Diputados y de la autorización parlamentaria de la prórroga a efectos del control jurisdiccional de los reales decretos de declaración y de prórroga; la inaplicabilidad al caso de la doctrina de la STC 83/2016 al concurrir circunstancias críticas distintas de las que justificaron la declaración del estado de alarma en diciembre de 2010; la necesidad de tener en cuenta la normativa internacional y europea de derechos humanos y su interpretación, en especial en relación con el derecho a ser oído públicamente y con las debidas garantías en los procesos, y la indefensión que la inadmisión del recurso produciría en los ciudadanos, que verían vaciada de contenido la garantía de la tutela de los derechos ante la jurisdicción ordinaria prevista en el artículo 53.2 de la CE y vetada la oportunidad de conocer el parecer de nuestro

\footnotetext{
40

El dictamen en torno a la competencia de la Sala Tercera del Tribunal Supremo para la tramitación y resolución del recurso núm. 001/0000099/2020 fue emitido por los profesores $F$. J. DÍAZ REVORIO, C. FLORES JUBERÍAS, C. RUIZ MIGUEL, A. RUIZ ROBLEDO Y J. M. VERA SANTOS el 27 de abril de 2020. Disponible en https://www.dropbox.com/s/shu9trxbnhzbuzw/Asunto\%20Curro-

\%20Dictamen\%20Firmado\%20.pdf?dl=0. A favor de la competencia de la Sala Tercera del TS para revisar los elementos reglados de estos decretos, también VILLAR CRESPO, G., "Comentario a la STC 83/2016: con motivo de la naturaleza de los decretos del Gobierno que declaran el estado de alarma", cit., pp. 27-36.
} 
más alto tribunal en torno al alcance de las limitaciones de derechos que vienen sufriendo. "Y ello -se subrayaba en el dictamen- sin que sea de recibo argumentar que el recurrente siempre podría acudir a la jurisdicción ordinaria en el caso de que fuera sancionado por incumplir alguna de las restricciones a la libre circulación que figuran recogidas en los Reales Decretos que se impugnan y discrepase con la fundamentación jurídica, la forma o la entidad de esa sanción, [porque] es evidente que no se puede obligar a un ciudadano que desee cuestionar los límites impuestos a sus derechos a actuar de forma ilícita para provocar una infracción administrativa que permitiera acudir ante la jurisdicción contencioso-administrativa”"

Por unidad de doctrina, la Sección Cuarta de la Sala Tercera decidió, sin embargo, estar a lo decidido en las resoluciones de la antigua Sección Séptima dictadas con ocasión del estado de alarma de 2010, que inadmitieron impugnaciones directas aduciendo que los decretos de declaración y de prórroga habían sido adoptados por el Gobierno en su condición de órgano constitucional y que la intervención del Congreso y el aval de la mayoría parlamentaria les hacía inmunes al control contencioso-administrativo. A diferencia, por tanto, de los dos primeros AATS que inadmitieron la 41

Dictamen en torno a la competencia de la Sala Tercera del Tribunal Supremo para la tramitación y resolución del recurso núm. 001/0000099/2020, cit., p. 12. En el mismo sentido se había pronunciado anteriormente G. VILLAR CRESPO, quien, muy crítico con la STC 83/2016, sostuvo que el control de la declaración del estado de alarma debía recaer en la jurisdicción contencioso-administrativa por ser una jurisdicción que confiere a los ciudadanos mayores garantías y posibilidades de control que la jurisdicción constitucional en los procedimientos de inconstitucionalidad, cuya legitimación está limitada, y en procesos de amparo. "[...] los elementos reglados, o la conformidad de un acto o reglamento con los parámetros señalados en la Ley que los habilita -afirmó el autor- son cuestiones no fiscalizables por el Tribunal Constitucional, sino únicamente por el contencioso-administrativo. En [...] la STC 83/2016, se ha dado precisamente tal paradoja: el Tribunal Supremo se declara incompetente para pronunciarse sobre los decretos que declaran el estado de alarma y el Tribunal Constitucional, en amparo, únicamente se manifiesta sobre la posible vulneración del artículo 24 de la CE. Nada se dice sobre si se cumplen, o no, los requisitos para declarar el estado de alarma [...]. Ni tampoco si, a la luz de la LOAES, es posible militarizar el espacio aéreo y someter a los controladores a la legislación militar, reduciendo algunos de sus derechos fundamentales. ¿Eran adecuadas, proporcionales o conformes a la ley las medidas adoptadas por el Gobierno a través del RD 1673/2010? Nunca lo sabremos, puesto que la STC 83/2016 no ha dado respuesta a ninguna de estas cuestiones". Cfr. "Comentario a la STC 83/2016: con motivo de la naturaleza de los decretos del Gobierno que declaran el estado de alarma", cit., pp. 35-36. Más crítico aún, tildando de "grosero" y "tosco" el pronunciamiento del TC y sosteniendo que el decreto de declaración tiene naturaleza reglamentaria sin que la autorización parlamentaria de la prórroga en sus mismos términos lo eleve de rango, SÁNCHEZ GARCÍA, J. Mạ.., "La declaración del estado de alarma. Los controvertidos caminos para su impugnación", en RECUERDA GIRELA, M. A. (dir.), Antes de la próxima pandemia, Thomson Reuters Aranzadi, Cizur Menor, 2020, pp. 124-125. 
impugnación de los decretos dictados en marzo y abril de 2020, los AATS $2478 / 2020$ y $2508 / 2020$ no aludieron para justificar la falta de jurisdicción al contenido normativo y a los efectos jurídicos de los decretos de declaración y de prórroga del estado de alarma, cuya fuerza y valor de ley reconoció la STC $83 / 2016$.

Los AATS $2478 / 2020$ y 2508/2020 citaron la doctrina de la STC $83 / 2016$, pero no asumieron ni avalaron sus argumentos porque, como se reconoció abiertamente, dicha sentencia fue "formulada por el Tribunal Constitucional al resolver un recurso de amparo y no en sede de tribunal de control de constitucionalidad de las leyes" (fundamentos de derecho $4^{\circ}$ y $2^{\circ}$, respectivamente). $\mathrm{Y}$ retomando la tesis expuesta en los AATS 857/2011, 2985/2011, 3816/2011 y 6821/2011, dictados con ocasión de la declaración del estado de alarma en 2010, la Sección Cuarta de la Sala Tercera del TS volvió a sostener, como si la STC 83/2016 no hubiera sido dictada, que la inmunidad ante la jurisdicción contencioso-administrativa de los decretos de declaración y prórroga del estado de alarma no deriva de sus efectos sobre el ordenamiento jurídico, sino de la autorización parlamentaria de la prórroga y de la asunción parlamentaria, a resultas de esa prórroga y de la previa dación de cuenta, de la propia declaración. "La dación de cuenta -se afirmó en el fundamento de derecho $6^{\circ}$ del ATS 2478/2020 y se asumió en el fundamento de derecho $2^{\circ}$ del ATS 2508/2020- al Congreso de los Diputados, a efectos del artículo 162 de su Reglamento, del Real Decreto 463/2020, de 14 de marzo, así como la previa autorización parlamentaria de los Reales Decretos de prórroga 476/2020, de 27 de marzo, 487/2020 de 10 de abril y el Real Decreto 492/2020, de 24 de abril, determinan que sean en este caso disposiciones de un valor normativo equiparable [...] al de las leyes y normas con fuerza de ley, cuyo control corresponde al Tribunal Constitucional por los mecanismos de control de la constitucionalidad de las leyes y no a esta Sala".

A fin de mostrar su insatisfacción con la doctrina de la STC 83/2016, el ponente decidió dar, sin embargo, un paso más, para afirmar, en coherencia con la tesis de la intervención parlamentaria como causa de la falta de jurisdicción, que "en aquellas situaciones en las que, no se haya producido la dación de cuenta al Congreso o no haya recaído la autorización de prórroga parlamentaria que exige el artículo 116.2 CE, la forma de decreto que revista la declaración de alarma pudiera recobrar su relieve a efectos de nuestro control jurisdiccional. Aunque el decreto de declaración de la alarma proceda del Gobierno como 
órgano constitucional, su control correspondería a esta Sala, como permite el artículo 2.a) de la LJCA, respecto de lo que en nuestra jurisprudencia hemos denominado conceptos judicialmente asequibles" (por todas, sentencia de 20 de noviembre de 2013 (rec. 13/2013) o sobre los hechos determinantes" (fundamento de derecho $4^{\circ}$ del ATS 2478/2020). En otros términos, la Sección Cuarta de la Sala Tercera del TS sostuvo que, en el caso de ser cuestionado en la dación de cuenta o no autorizarse la prórroga, el decreto de declaración perdería su fuerza de ley, recuperaría la naturaleza reglamentaria propia de los decretos y podría ser revisado por la jurisdicción contencioso-administrativa. Así las cosas, el TS atribuyó dos naturalezas alternativas al decreto de declaración: la de acto con fuerza de ley y la de reglamento, cuya alteridad no depende de su contenido, sino de su confirmación parlamentaria que, de producirse, confiere valor de ley al decreto de declaración. En caso contrario, el decreto recuperaría su naturaleza reglamentaria y podría ser controlado por la jurisdicción ordinaria. $\mathrm{Y}$ ello, contrariamente a la lógica y la seguridad jurídicas y a la doctrina de la STC 83/2016 sobre los decretos y resoluciones de declaración y de prórroga de los estados excepcionales en nuestro ordenamiento constitucional, por más que ésta fuera formulada en un proceso de amparo y no en un juicio de constitucionalidad.

IV. EPÍLOGO: A LA ESPERA DEL PROCESO DE INCONSTITUCIONALIDAD QUE CONFIRME LA FUERZA DE LEY Y LA RESERVA DEL CONTROL DE LOS DECRETOS DE DECLARACIÓN Y DE PRÓRROGA DEL ESTADO DE ALARMA A LA JURISDICCIÓN CONSTITUCIONAL

Aunque en situaciones de crisis las limitaciones y los controles constitucionales puedan ser mermados, la Constitución ha de mantener activas sus garantías jurisdiccionales porque las decisiones excepcionales pueden vulnerar la normatividad constitucional declarando la excepción al margen de sus supuestos, sin respetar el procedimiento o adoptando medidas exorbitantes. Debido a su extraordinario alcance político, alguna doctrina ha sostenido que las decisiones excepcionales les plus importantes doivent échapper au juge ${ }^{42}$, pero los ordenamientos constitucionales más avanzados no han dudado en someterlas a control jurisdiccional. En unos casos, ante los tribunales

${ }^{42}$ CAMUS, G., L'état de nécessité en démocratie, cit., p. 346. 
contencioso-administrativos. En otros, ante la jurisdicción constitucional, subrayando, de este modo, frente a la eventualidad de la crisis, que la distinción entre poder constituyente y poderes constituidos no sólo opera en el momento fundacional, sino que sustenta el orden jurídico estatal incluso en situaciones excepcionales. El problema en España es que este control de las decisiones de declaración y prórroga de los estados excepcionales no ha sido previsto ni constitucional, ni legalmente. Y la doctrina ha discrepado tanto de su viabilidad como del órgano jurisdiccional al que encomendarlo. Ello se ha debido a la singular naturaleza de estas decisiones excepcionales, cuyo procedimiento de adopción en el caso del estado de alarma es muy distinto según se trate de la declaración del estado o de su prórroga.

El Gobierno declara el estado de alarma mediante decreto, dando cuenta posteriormente al Congreso. El Gobierno también prorroga el estado de alarma, pero es el Congreso de los Diputados quien determina en su autorización el alcance y las condiciones del estado prorrogado. Debido a la diversidad de procedimientos y de órganos implicados, alguna doctrina sostuvo que los decretos de declaración no podían tener la misma naturaleza que los decretos de prórroga y, consecuentemente, tampoco podían ser controlados por los mismos órganos jurisdiccionales. Adoptado unilateralmente por el Gobierno, el decreto de declaración sería una disposición reglamentaria; el decreto de prórroga, en cambio, formalizaría una decisión parlamentaria tan sólo controlable por la jurisdiccional constitucional. Pese a esa gestación diversa, otra doctrina defendió que ambos decretos tenían la misma naturaleza. Para algunos, debían ser considerados reglamentos sometidos al principio de legalidad y revisables por la jurisdicción ordinaria. Para otros, tanto la declaración como la prórroga son decisiones directamente incardinadas en la CE y, dado su carácter primario y efectos, su control debía reservarse a la justicia constitucional.

La declaración del estado de alarma en diciembre de 2010 para hacer frente al caos provocado en los aeropuertos españoles llevó el problema de la revisión jurisdiccional de estas decisiones al terreno práctico, al interponer los controladores afectados sendos recursos contencioso-administrativos contra los decretos de declaración y de prórroga dictados por el Gobierno, un recurso de amparo por vulneración de derechos fundamentales contra la autorización parlamentaria del decreto de prórroga y un segundo recurso de amparo contra 
los AATS que inadmitieron la revisión jurisdiccional de los decretos de declaración y de prórroga por falta de jurisdicción.

El Tribunal Supremo rechazó controlar los decretos de declaración y de prórroga del estado de alarma aduciendo que la prórroga había sido autorizada por el Congreso en los mismos términos que la declaración, lo que a su juicio impedía revisar tanto el decreto de prórroga como el de decreto de declaración, cuya necesidad y regularidad habían sido ratificadas parlamentariamente.

Para el Tribunal Constitucional, que se pronunció en 2016 a resultas del recurso de amparo presentado contra varios de esos AATS, la causa de la exclusión del control jurisdiccional ordinario de los decretos de declaración y de prórroga del estado de alarma no podía residir, sin embargo, en la autorización parlamentaria de la prórroga, sino en la naturaleza y en la posición que en el sistema de fuentes ocuparan, por sí mismos, dichos decretos. Y, desde este punto de vista, los decretos de declaración y de prórroga de la alarma debían considerarse actos con fuerza de ley que desplazan o suspenden temporalmente la aplicabilidad de leyes y otras normas con rango de ley al tiempo que confieren validez a las disposiciones y los actos administrativos adoptados a su amparo. A juicio del TC, que compartimos plenamente, los decretos de declaración y de prórroga del estado de alarma no son actos discrecionales del Gobierno sometidos al control de la jurisdicción contenciosoadministrativa en punto a sus elementos reglados exartículo 2.a) LJCA, ni manifestación de su potestad reglamentaria. Pese a su diversa gestación, los decretos de declaración y de prórroga del estado de alarma son actos de idéntica naturaleza que activan y completan el sistema de fuentes del derecho de excepción determinando, en cada caso, el régimen jurídico aplicable. No se incorporan al ordenamiento ni lo modifican propiamente, por lo que no son normas en sentido estricto, pero ocupan el lugar de una verdadera norma que opera como título de habilitación y canon de legalidad para las disposiciones y los actos extraordinarios que dicte la autoridad competente ${ }^{43}$. Los decretos de

\footnotetext{
${ }^{43}$ Los decretos de declaración y de prórroga del estado de alarma no sólo operan como fuente sustantiva de derecho, sino, asimismo, como título habilitador de otras normas "por cuanto que habilitan a determinadas autoridades para crear un derecho derivado de la declaración [o la prórroga] que, junto con ella, conforma la legalidad de excepción que desplaza la legalidad ordinaria" completando las previsiones de la LOAES y las de la propia declaración o prórroga, a las que los artículos 7 y 11 de la LOAES reservan, no obstante, las medidas limitativas de derechos sin que resulte procedente en este ámbito su deslegalización en beneficio de las normas derivadas. Cfr. CANOSA USERA, R: "Ordenación de las fuentes del derecho en estados de emergencia sanitaria. El caso español", en BARCELÓ ROJAS, D.; DÍAZ RICCI, S.;
} 
declaración y de prórroga son actos primarios directamente infraordenados a la Constitución, cuyas previsiones, por reserva expresa del constituyente, han sido completadas por la LOAES, lo que amplía el parámetro o canon de enjuiciamiento de dichos decretos, pero no cuestiona su fuerza de ley, ni convierte su control jurisdiccional en un control de mera legalidad, porque al excepcionar o modificar pro tempore determinadas disposiciones legales, su control sólo puede ser de constitucionalidad y sustanciarse ante el Tribunal Constitucional.

Pese a la rotundidad de la STC 83/2016, que caracterizó sin reservas ni votos particulares discrepantes los decretos de declaración y de prórroga del estado de alarma como actos del Estado con fuerza de ley, la cuestión distaba de ser pacífica y su posición en el sistema de fuentes siguió siendo controvertida. "Sea cual sea la naturaleza del decreto por el que se declara el estado de alarma -replicó alguna doctrina-, y actúe el Gobierno en la condición que se quiera, su sometimiento a las leyes es indiscutible. $Y$ la competencia de los tribunales para juzgarla, inaplazable. Se trata, además, de una postura ya sustentada por el Tribunal Constitucional; sin ir más lejos en el caso de los decretos legislativos. A pesar de las polémicas doctrinales iniciales, tras la LJCA ha quedado claro que esta jurisdicción también asume su control cuando excedan los límites de la delegación (exart. 1.1 LJCA). Si una norma con rango de ley procedente del Gobierno puede ser controlada por la jurisdicción cuando excede de la autorización o las bases, mutatis mutandis (o incluso, a fortiori) debe poder serlo una norma formalmente con rango de decreto, aunque el Tribunal Constitucional la haya equiparado a las de rango de ley" ${ }^{44}$.

Y la discusión sobre la doctrina contenida en la STC 83/2016 no se ha limitado al ámbito académico, puesto que, al haberse dictado en un proceso de amparo y carecer de los efectos de las sentencias de inconstitucionalidad, también ha sido cuestionada por la Sección Cuarta de la Sala Tercera del TS con ocasión de la inadmisión de dos recursos contencioso-administrativos presentados contra el Real Decreto 463/2020, de 14 de marzo, de declaración del estado de alarma para la gestión de la crisis sanitaria ocasionada por la covid-19 y sus

GARCÍA ROCA, J. y GUIMARÁES TEIXEIRA, Ma․ E. (coords.), COVID-19 y parlamentarismo. Los parlamentos en cuarentena, Universidad Autónoma Nacional de México e Instituto de Derecho Parlamentario, México, 2020, p. 277.

${ }^{44}$ DÍAZ REVORIO, F. J.; FLORES JUBERÍAS, C.; RUIZ MIGUEL, C.; RUIZ ROBLEDO, A. y VERA SANTOS, J. M., Dictamen en torno a la competencia de la Sala Tercera del Tribunal Supremo para la tramitación y resolución del recurso núm. 001/0000099/2020, cit., p. 6. 
primeros decretos de prórroga. En los AATS 2478/2020 y 2508/2020, el TS ha rechazado el control de dichos decretos, pero no con los argumentos contenidos en la STC 83/2016, a los que no se considera vinculado, sino aduciendo nuevamente la autorización parlamentaria como causa ex post facto de la falta de jurisdicción. Y extrayendo las consecuencias de dicha tesis, ha conjeturado sobre la posibilidad de que los decretos de declaración del estado de alarma presenten dos naturalezas alternativas: la de actos con fuerza de ley si se solicita su prórroga y ésta es autorizada por el Congreso de los Diputados, en cuyo caso su control corresponde a la justicia constitucional, o la de disposiciones reglamentarias revisables por el Tribunal Supremo en el supuesto de eludir la dación de cuenta, de no solicitarse su prórroga o de que, solicitada por el Gobierno, no sea autorizada por el Congreso de los Diputados. En otros términos, el TS atribuye dos posibles naturalezas al decreto de declaración, cuestionando la doctrina del TC, añadiendo inseguridad jurídica y volviendo al punto de partida.

Así las cosas, habrá que esperar a la resolución del recurso de inconstitucionalidad interpuesto el 28 de abril de 2020 por los 52 diputados del Grupo Parlamentario de Vox contra el Real Decreto 463/2020, de 14 de marzo, de declaración del estado de alarma para la gestión de la crisis sanitaria de la covid-19, y varios de los Reales Decretos que lo prorrogaron para que el Tribunal Constitucional pueda ratificar, en su caso, su doctrina precedente en punto a la posición en el sistema de fuentes de dichos decretos, confiriéndole así, al reproducir sus argumentos en una sentencia dictada en un procedimiento de inconstitucionalidad, los efectos generales y vinculantes para todos los poderes públicos que permitan zanjar la cuestión y delimitar en nuestro ordenamiento jurídico los ámbitos propios de la jurisdicción ordinaria y de la justicia constitucional frente a las decisiones de excepción. 